\title{
Comparison of time perception between subjects with major depression disorder and normal subjects using emotional stimuli
}

\author{
Mahsa Ghaheri"** AD, Amir Hossein Ghaderi², Hamid Reza Nikyar \\ 1. MA of Clinical Psychology, Department of Psychology, Najafabad Branch, Islamic Azad University, Najafabad, Iran \\ 2. PhD in Cognitive Neuroscience, Cognitive Neuroscience Lab, Department of Psychology, University of Tabriz, Tabriz, Iran \\ 3. Associate Professor of Medical Faculty, Clinical research, Development Center, Najafabad Branch, Islamic Azad University, \\ Najafabad, Iran
}

Recieved: 8 Apr. 2018

Revised: 27 Jun. 2018

Accepted: 2 Jul. 2018

\section{Keywords}

Major depressive disorder (MDD)

Time perception

Time discrimination

Emotion

Corresponding author

Mahsa Ghaheri, MA of Clinical Psychology, Department of Psychology, Najafabad Branch, Islamic Azad University, Najafabad, Iran

Email: Mahsaghaheri@yahoo.com

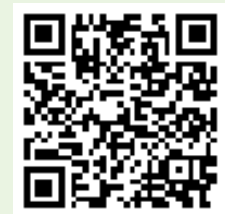

doi doi.org/10.30699/icss.21.2.121

\section{Abstract}

Introduction: Depression is a mood disorder that changes the individual's subjective experience of time. On the other hand, emotion can affect time perception, which its importance in performing activities and projecting future is well known to everyone. The aim of the present study was to compare the effect of different emotional stimuli (happy, sad and neutral) on the time perception in people with and without major depression disorder (MDD).

Methods: The current research was an analytical descriptive study. Fifteen patients with major depressive disorder with psychiatric diagnosis referred to psychiatric clinics of $\mathrm{Na}$ jaf Abad were selected randomly using the convenience sampling and. The control group contained 15 people without mental disorders. Two groups were matched in terms of demographic characteristics. For a better understanding of the subjects, from each person took Beck depression inventory before time perception task, then time perception task in the four stages was taken for them.

Results: The results showed that time discrimination between two groups was significantly different and oddball stimuli were underestimated by the MDD group.

Conclusion: The mood of sadness in depressive individuals is associated with the slowing of the internal clock speed, internal clock runs more slowly than normal in depressive people that can lead to underestimation of time. Also, attention-deficit disorder in depressive patients has been proved that can cause time distortions and reducing sensitivity to time and, in turn, disrupt time discrimination in these people. 


\title{
مقايسه ادراك زمان محر كهاى داراى بار هيجانى در افر اد مبتلا به افسردكى اساسى و تروه بهنجار
}

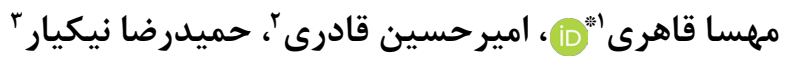

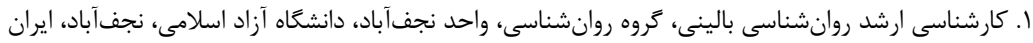

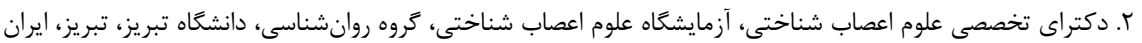

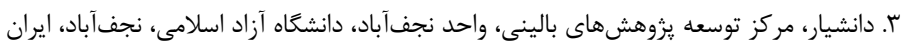

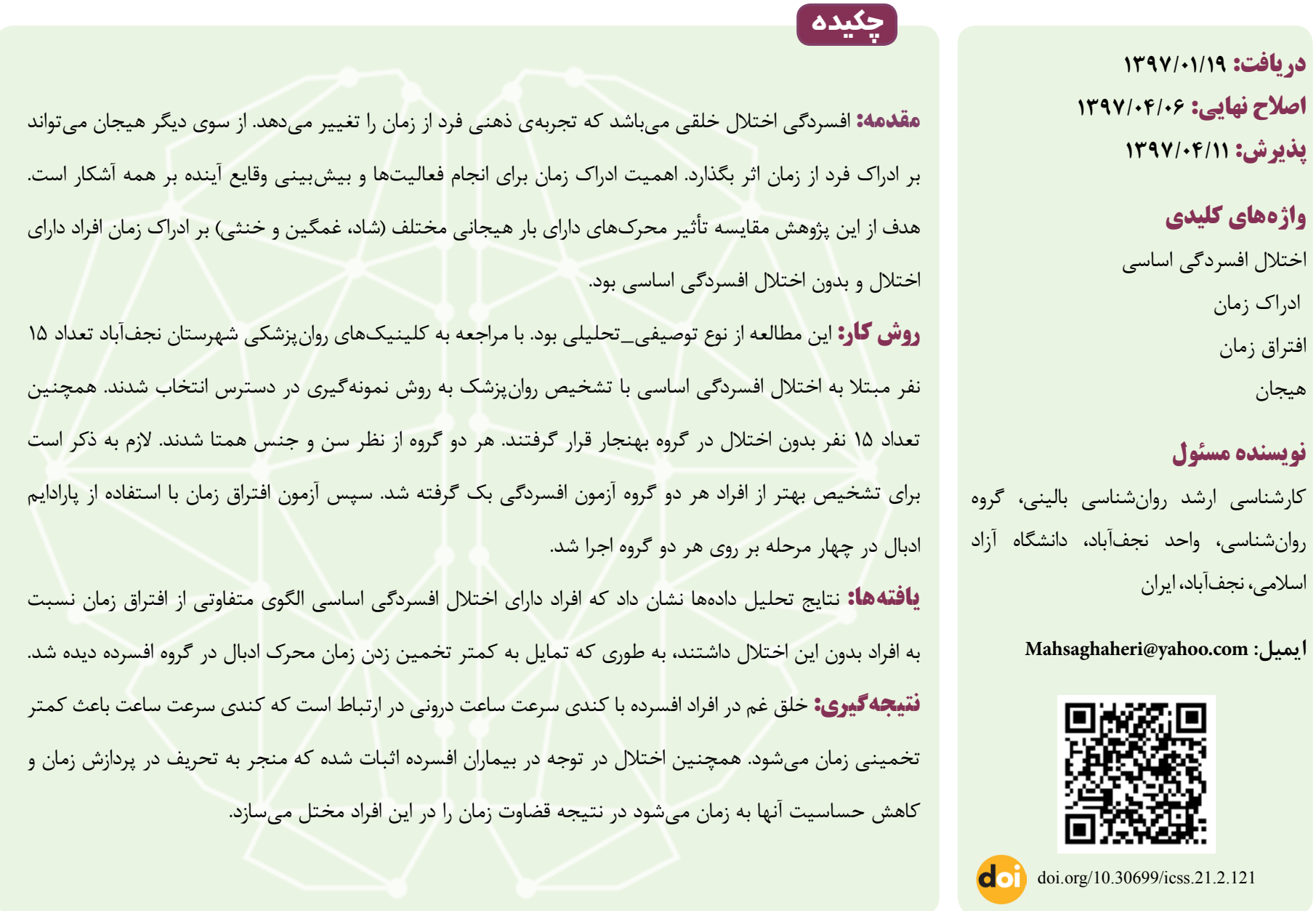

مقدمه

مانند حافظهى كارى، توجه، كنترل تكانه و سرعت پردازش مىتواند بر

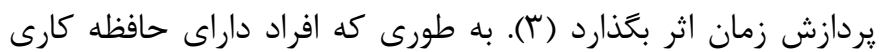
قوى و با توانايى توجه و دقت بهتر، توانايى زمانى بهترى نيز دارند (r). نقص ادراك زمان در كودكان مبتلا به اختلال بيش فعالى و نقص توجه در تكاليف مختلف زمانى نشان داده شده است (أ-G) اين مىتواند به
ادراك زمان توانايى ضرورى براى انجام فعاليتهاى روزمره و پيشبينى وقايع آينده است ( (1). انجام فعاليتهاى مختلف مستلزم برنامهريزى، مدريت زمان، تخمين و برآورد دقيق زمان است. بسيارى از مبتلايان به اختلالات روانشناختى از جمله اتيسم، بيش فعالى و نقص توجه، اسكيزوفرنى نقص در ادراك زمان دارند (ז). كاركردهاى اجرايى مختلف رئ 
سالم است (91). ساعت درونى از نخستين و معروفترين مدلهاى اختصاصى ادراك زمان مىباشد؛ يعنى مكانيسم عصبى خاصى در مغز

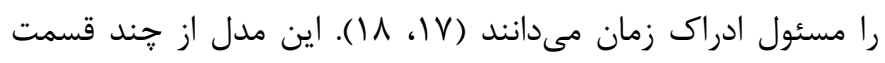
تشكيل شده است. نبضساز كه سازندهى پالس است پالسهايى را

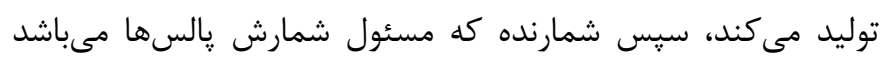
آنها را در حافظهى كارى ذخيره مى كند. در زمان تصميهميرى فرد به مقايسه ميزان يالس ذخيره شده در حافظهى كارى با مقاديرى كه از قبل در حافظهى مرجع ذخيره شده است مىيردازد. هر جِقدر ميزان يالس بيشترى ذخيره شده باشد فرد زمان را طولانىتر در نظر مى

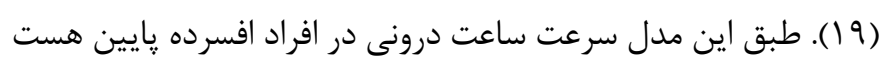
در نتيجه يالس كمترى در واحد زمان انباشته مىشود و به اين ترتيب

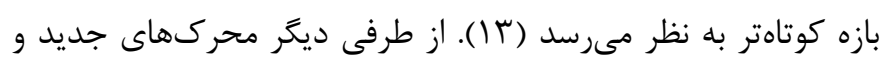

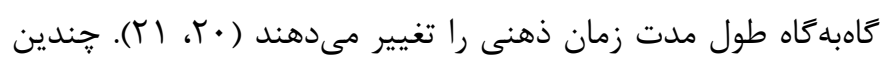
مطالعه گزارش كردهاند محركهاى تكرارى نسبت به محرك جديد و

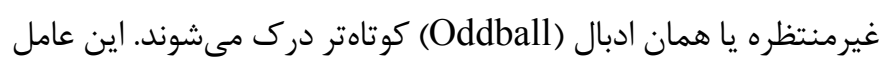
مىتواند در ارتباط با سركوب تكرار (Repetition suppression) باشد. مفهوم سركوب تكرار توسط Eagleman در سال ^ • • ب مطرح شد (Tr). سركوب تكرار اين را بيان مى كند كه تكرار جندين باره يك محرك باعث كاهش فعاليت عصبى در مغز مىشود، در نتيجه انرزى كمترى در مغز توليد مىشود و فرد زمان ارائه محرك را كمتر از

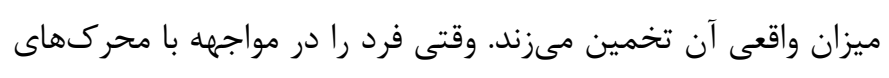
تكرارى قرار مىدهيه كه در بين آنها، محرك جديد يا ادبال به فرد عرضه مىشود فعاليت يكباره مغز به هنعام رويارويى با محرك جديد افزايش مىيابد. افزايش فعاليت عصبى منجر به افزايش زمان درى شده

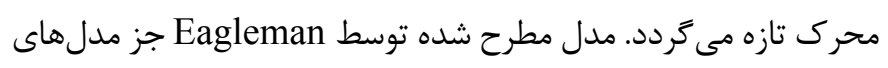

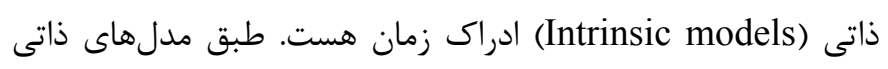
مكانيزم اختصاصى براى ايجاد زمان وجود ندارد و فعاليت كلى مغز و وانى انرزِى كلى صرف شده در مغز زمان را براى ما مىسازد. صرف انرزى إنى بيشتر و فعاليت عصبى بيشتر در مغز منجر به درك طولانىتر زمان

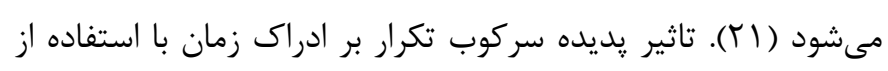
محركهاى شنيدارى در مطالعه نظرى و جلال كمالى نشان داد كه ارائه محرك ادبال صوتى بعد از جندين بار ارائه محركهاى استاندارد منجر به افزايش زمان ادراك شده مى گردد (سT). مطالعات قبلى نشان مىدهد داراى بار عاطفى و هيجانى بودن محركها اثرى بر روى اين قضيه در افراد عادى نداشته است (YT)؛ اما هيج تحقيقى راجع به افراد داراى افسردگى اساسى وجود ندارد ولى به نظر مىرسد محركهاى هيجانى اثر بيشترى بر روى افراد افسرده دارند
دليل نقص در حافظهى كارى باشد كه نقش مهمى در ادراك زمان

$$
\text { بازى مى كند (V) }
$$

وجود نواقص شناختى در كاركردهاى اجرايى افراد افسرده به خوبى مشخص شده است. برخى از يزوهشها نشان دادهاند كه افراد افسرده در برخى از كاركردهاى اجرايى مانند حافظه كارى، توجه و تصميم

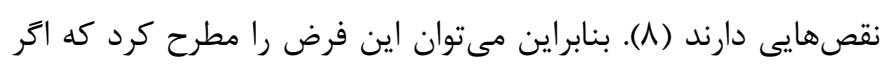
ادراك زمان با حافظهى فعال يا توجه ارتباط دارد يس مى مىتوان انتظار داشت ادراك زمان در افراد داراى افسردگى مختل شده باشد. شواهد تجربى حاكى از آن است كه افراد افسرده درك متفاوتى از زمان دارند (9، • (1) و اكثراً اظهار مى كنند زمان براى آنها به كندى مى كذرد ( • (1). نتايج حاصل از مطالعات مربوط به ادراك زمان در افراد افسرده متناقض

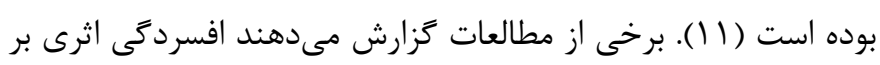
ادراك زمان ندارد (r ( ). در مقابل مطالعات ديخر به اين نتيجه رسيدهاند كه خلق افسرده با كاهش حساسيت بر زمان بر قضاوت فرد از زمان اثر مى گذارد (1 (1). با اين حال وقتى كه در مطالعات تحريف زمان مشاهده مىشود اظهارات بيماران افسرده اغلب به صورت كمتر تخمينى زمان مىباشد (r I). Gil و Droit-Volet در مطالعهاى بر تأثير افسردگى و احساس ناراحتى بر ادراك زمان به اين نتيجه رسيدند كه هر جه نمره

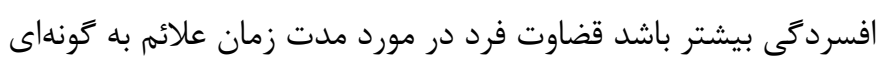
هست كه علائم را كوتاهتر مىبينند (11). اين نتايج نشان مى (1) بـهد مدت زمان تحقيق، توسط شركت كنندههاى داراى افسردگى، كمتر در نظر زرفته مىشود. علاوه بر آن طبق كفتههاى Sévigny و همان تمكاران تمايز زمانى در افراد افسرده نسبت به افراد غير افسرده، بايد ضعيفتر

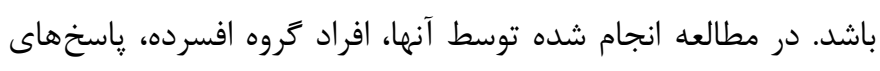

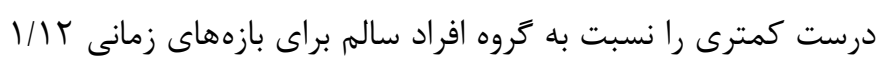

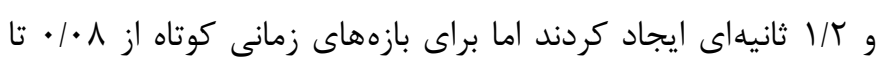

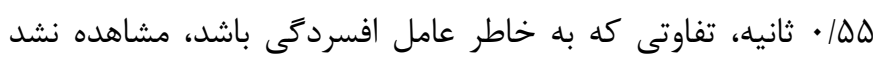

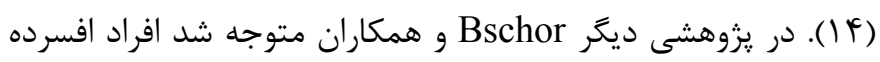

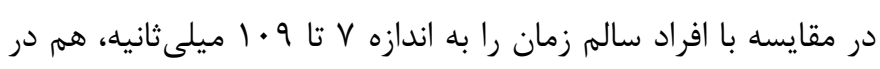

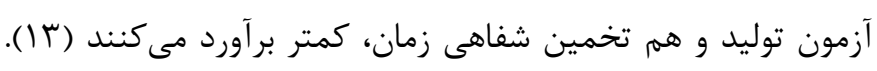
در مقابل Oberfeld و همكاران نتيجهاى مبنى بر اينكه افراد افسرده

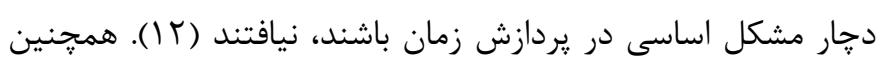
Thones جشمخير و قابلتوجهى بر ادراك زمان ندارد فقط كرايش به عملكرد

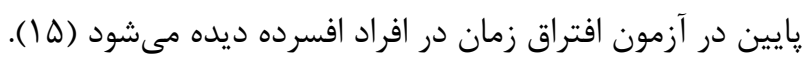
محققان بر اين باورند كه يايين بودن سرعت ساعت درونى در افرادى ردى

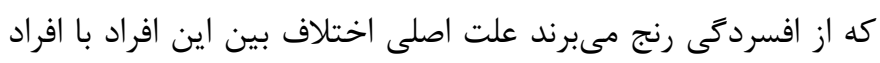


عنوان كروه كنترل انتخاب شدند كه از نظر سن و جنس با افراد افسرده

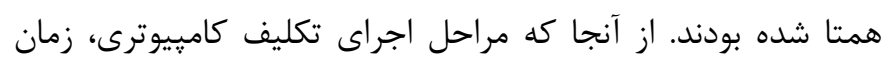

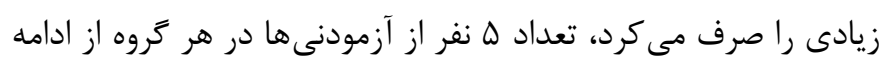

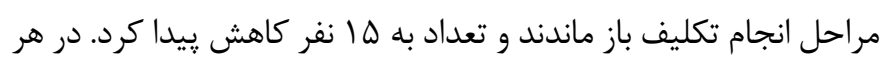

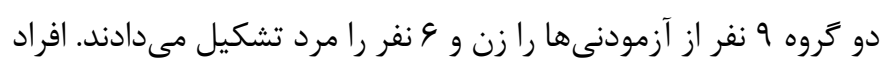

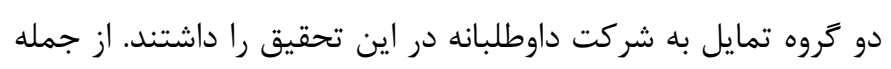

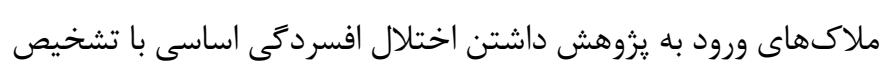
روانيزشك و نمره افسردكى بك، داشتن سطح تحصيلات دييلهم به بالا،

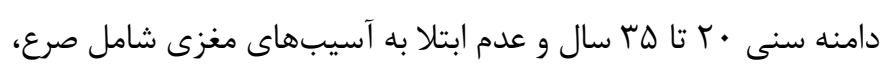

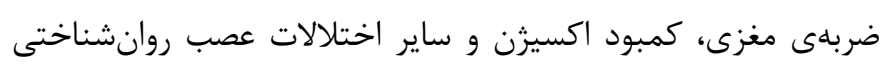

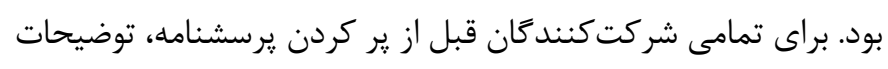

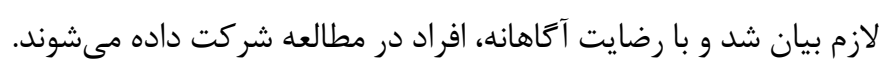

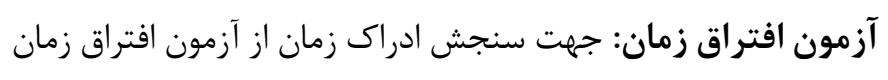

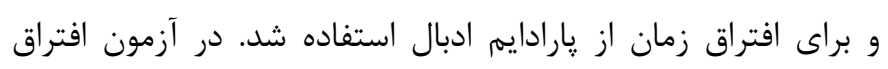

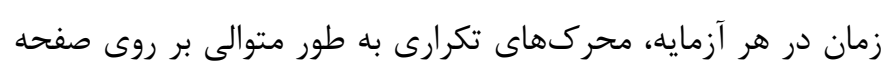

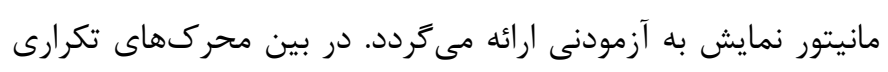

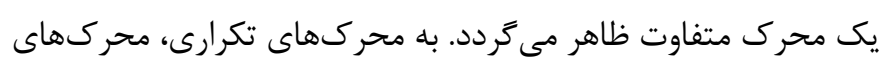

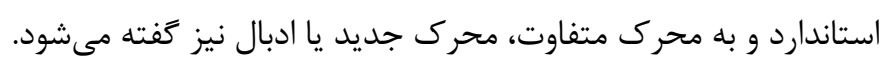

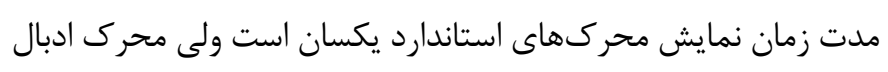

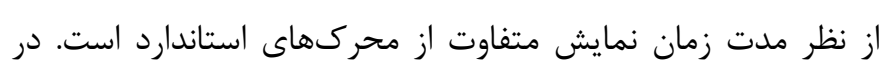

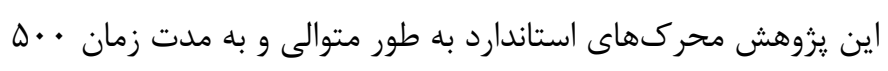

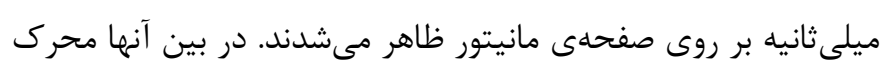

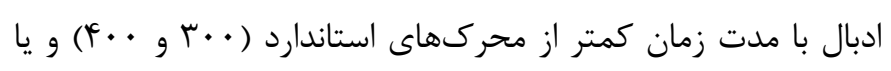

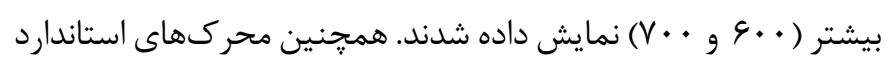

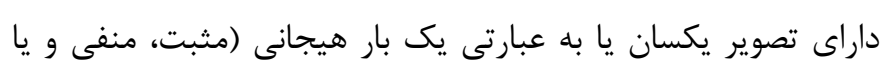

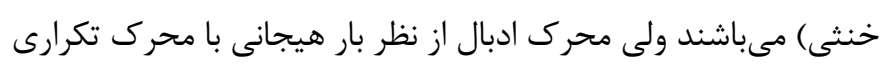

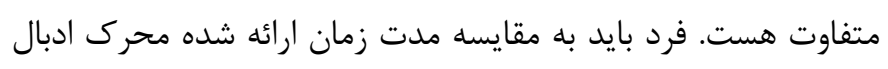

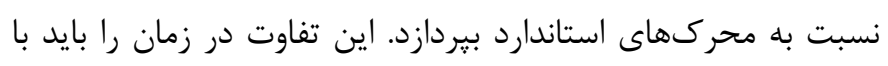

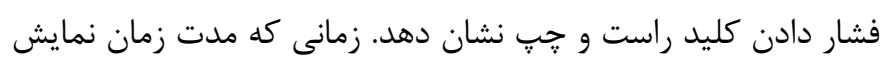

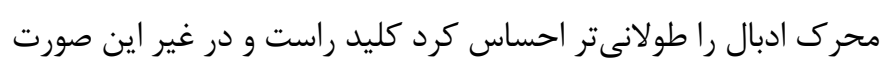

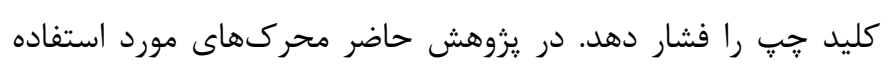

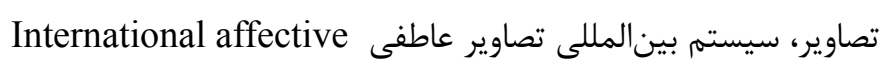
picture system (IAPS) همكاران (·r) هنجاريابى و متناسب با فرهنَ ايرانى انتخاب شدهاند.

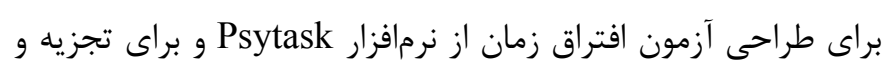

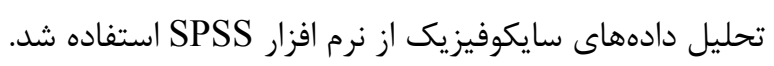

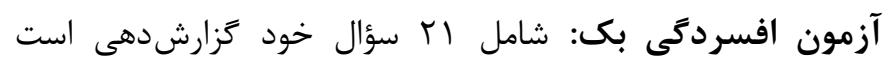

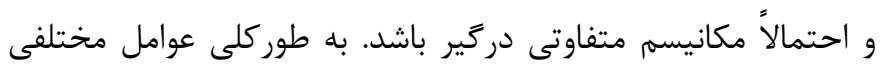

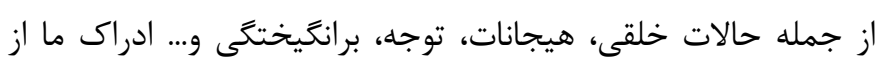

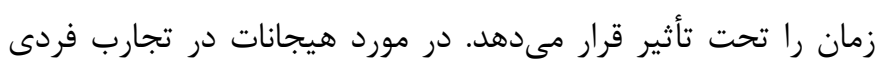

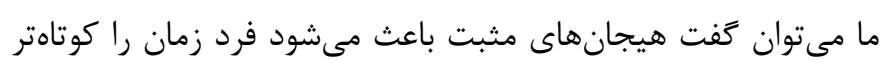

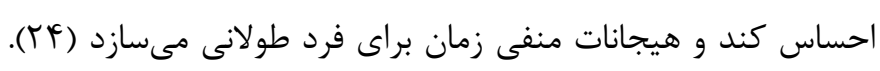

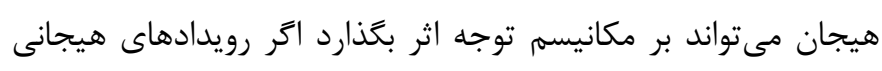

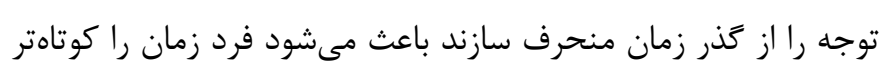
احساس كند. يافتهاى نظرى و همكارانش نيز نشان داد كه هيجان

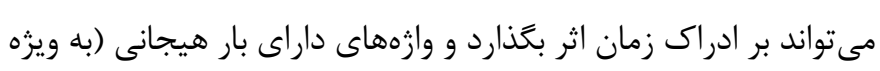

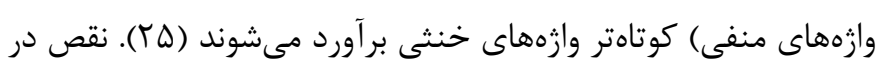

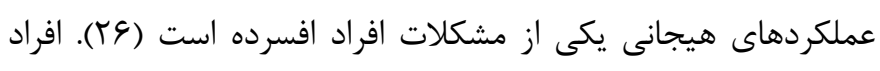

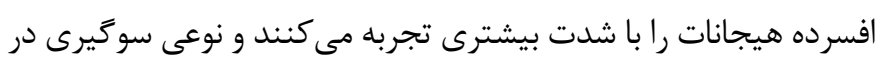

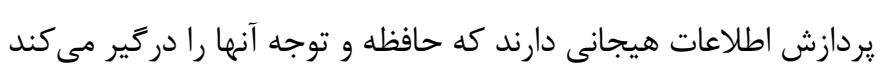
(YV)

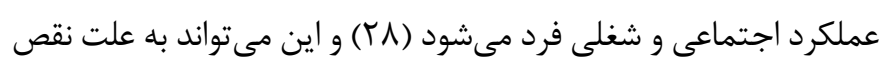

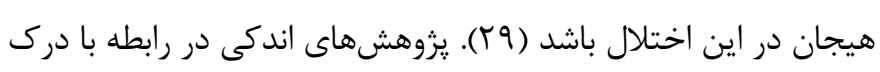

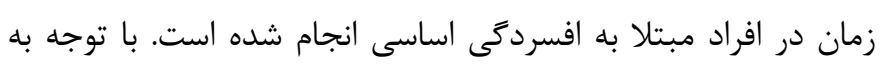

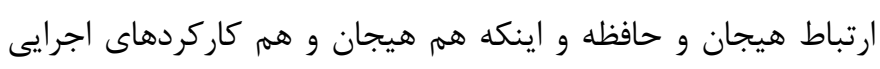

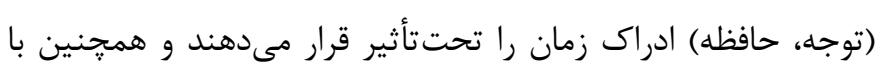

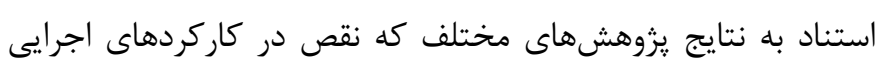

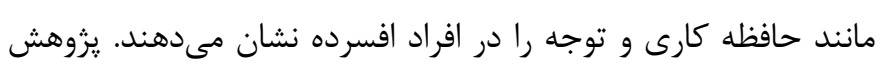

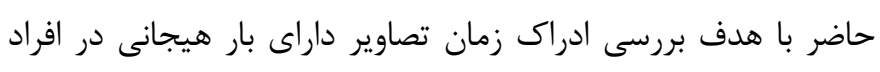

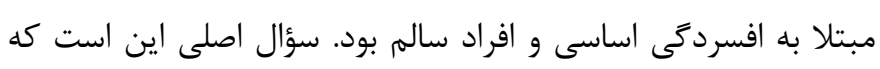

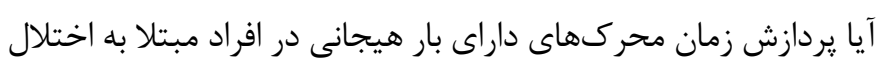

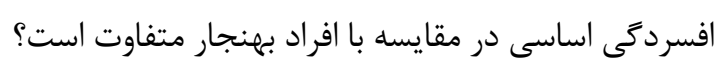

\section{روش كار}

يروهش حاضر از نوع توصيفى_تحليلى بود. جامعه آمارى يزوهش حاضر

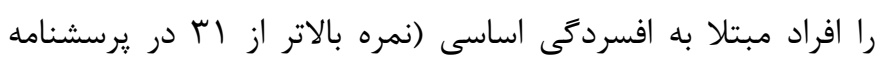

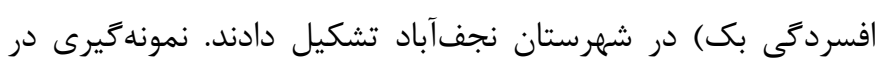

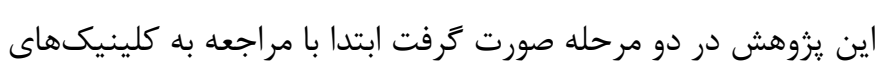

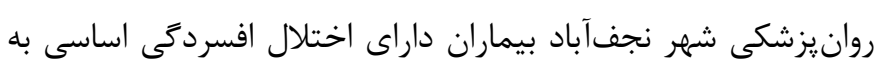

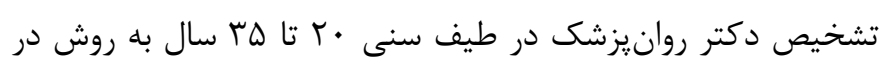

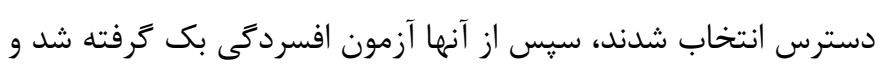

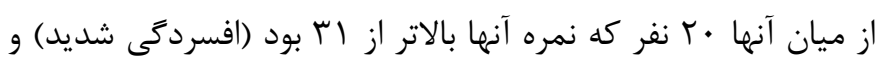

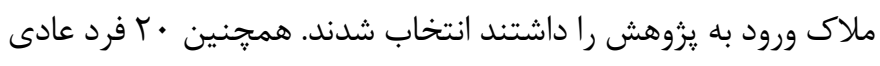

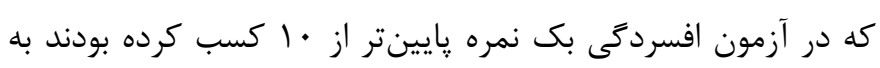


تصاوير بيردازى و تشخيصدهى كه مدت زمان نمايش تصوير متفاوت

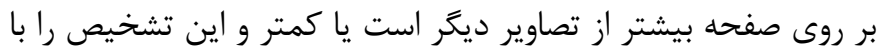

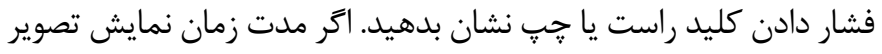

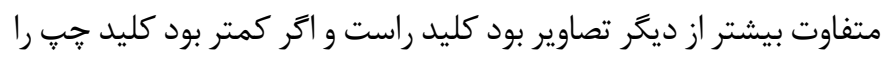

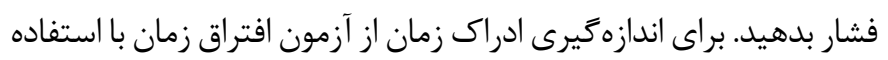
از ايانه استفاده شد. فاصله بين محركها Interstimulus interval

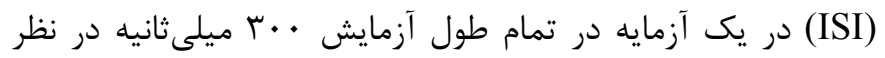

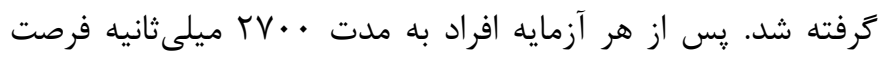

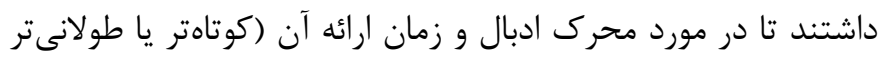

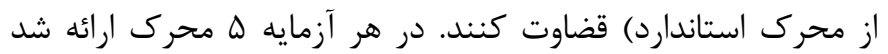

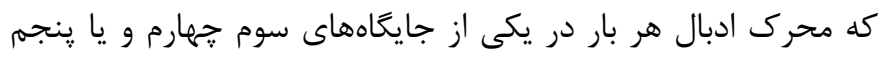

$$
\text { بلهورت تصادفى قرار مى كيرد. }
$$

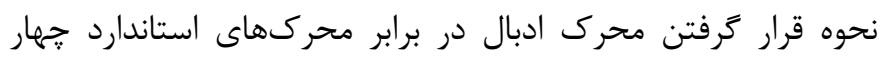

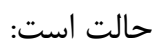

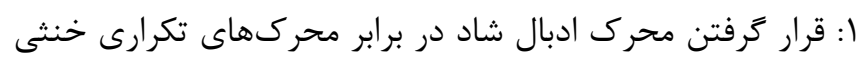

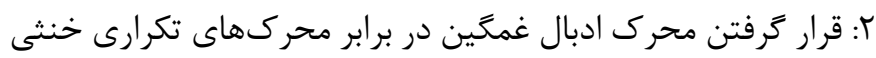

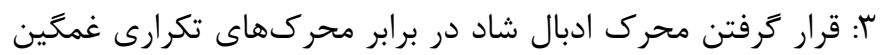

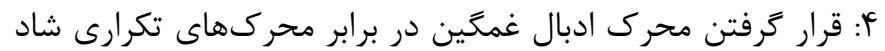

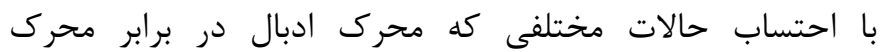

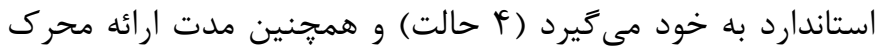

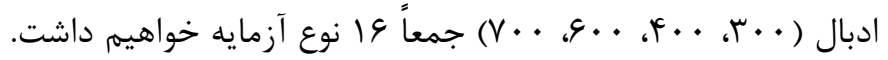

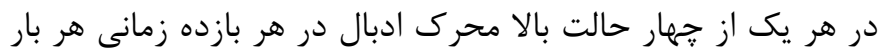

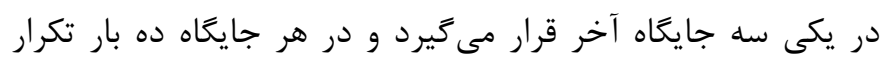

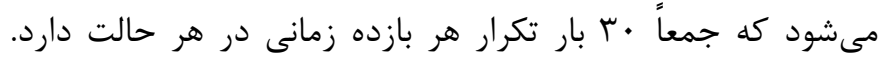

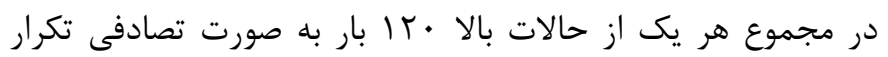

محتواى اين يرسشنامه، به طور جامع نشانهشناسى افسردگى است،

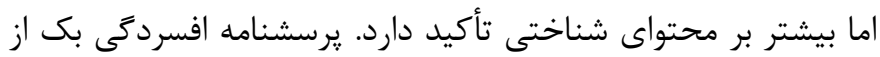
نوع آزمونهاى خودسنجى است و در ينج تا ده دقيقه تكميل مى شئود.

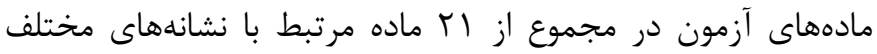

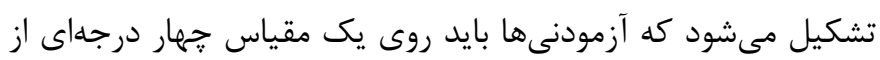

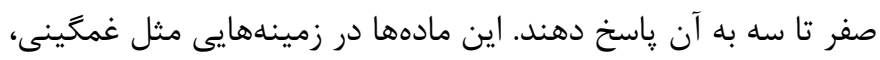

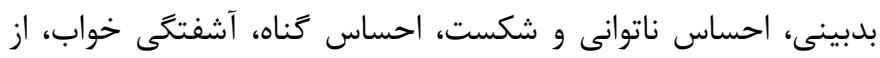
دست دادن اشتها، از خود بيزارى و ... هستند. اين مقياس، درجات مختلف افسردكى را از خفيف تا بسيار شديد تعيين مى كند و دامنه

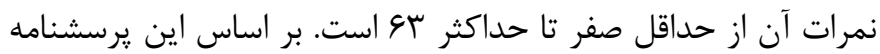
درجات افسردگى به اين صورت تقسيم بندى مىشود: نمرات كمتر از

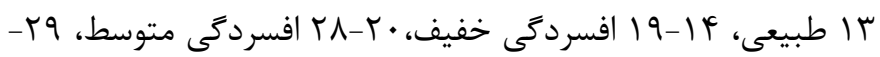

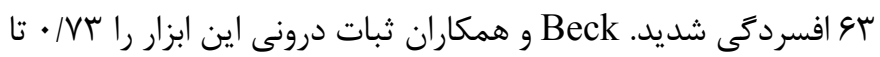

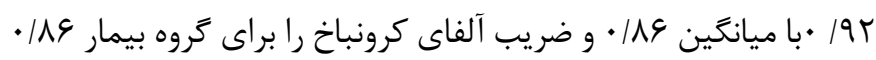

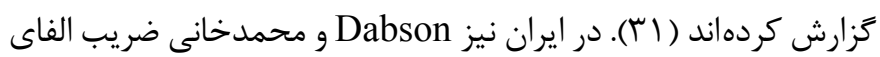

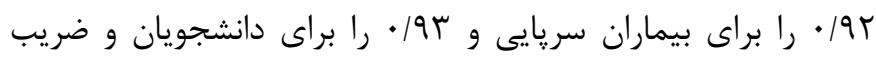

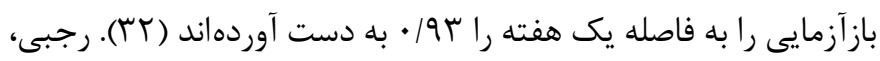
عطارى و حقيقى ضريب آلفاى كرونباخ را براى كل يرسشنامه AV| • و

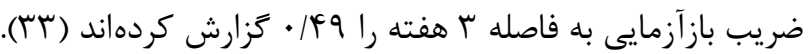

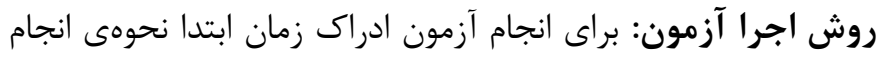

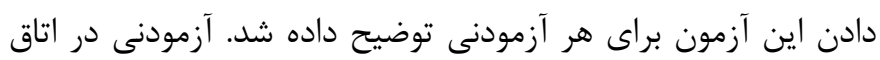

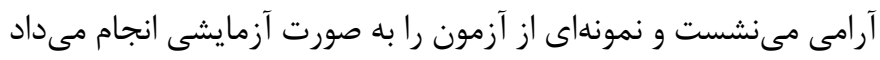

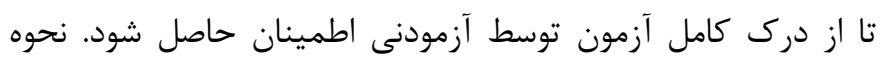

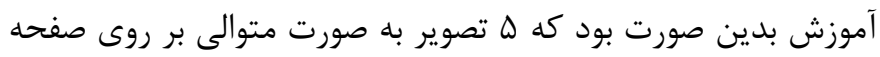

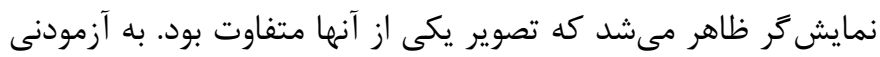
كفته مى شد بايد به مقايسه مدت زمان نمايش تصوير متفاوت را با ديخر

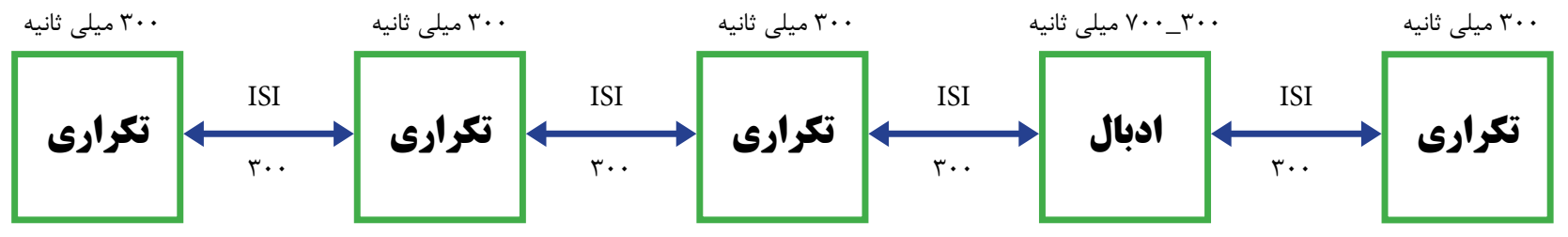



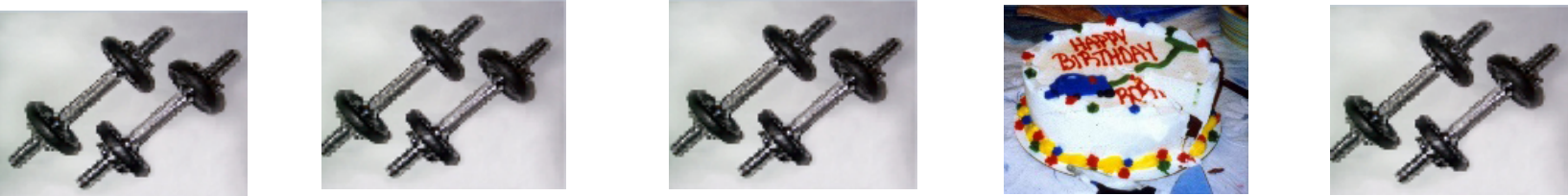

شكل r. حالت اول
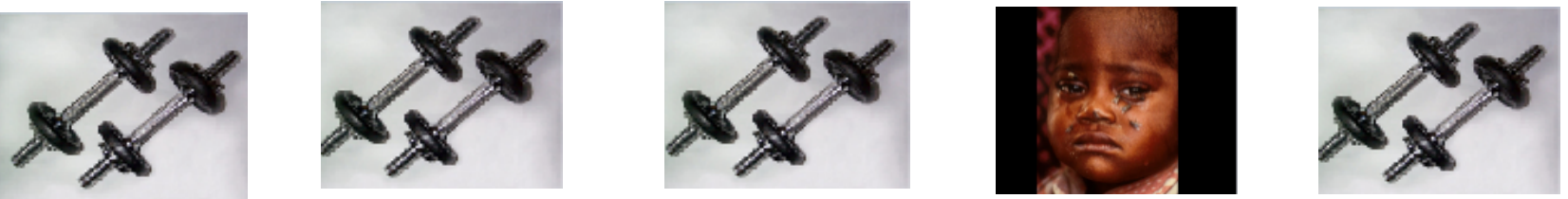

شكل س. حالت دوم
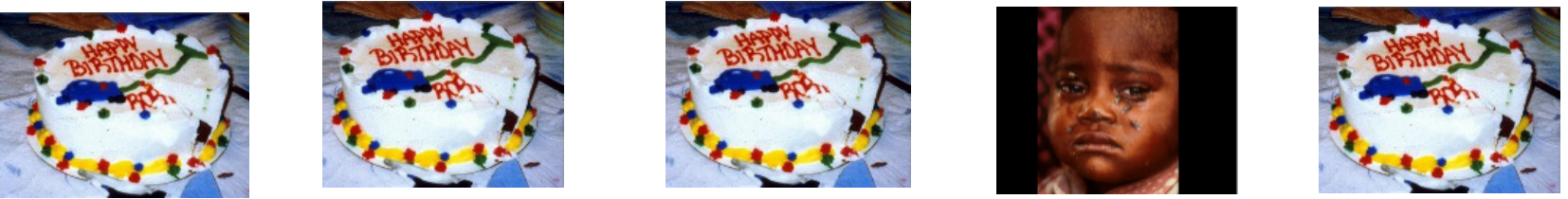

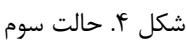
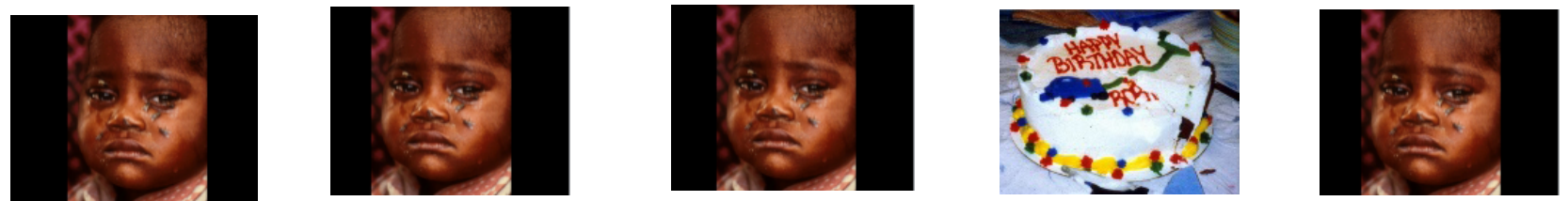

شكل ه. حالت حهارم

يافته ها

دو گروه افراد بهنجار و افسرده تفاوت معنادارى وجود داشت (r • • (P=). جدول r نتايج مقايسههاى زوجى براى فرضيههاى فرعى يزوهش نشان مى دهد: الف: افتراق زمان قرار كرفتن محرك ادبال شاد و غمحين در برابر محركهاى تكرارى خنثى در افراد مبتلا به اختلال افسردىى اساسى و كروه بهنجار متفاوت است. ب: افتراق زمان قرار كرفتن محرك ادبال

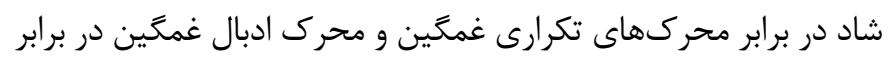
محركهاى تكرارى شاد در دو گروه متفاوت است. بر اساس يافتهها

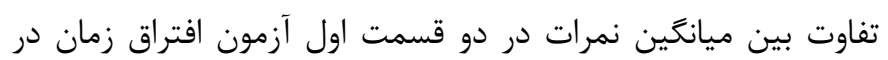

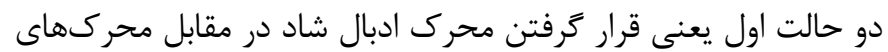
تكرارى خنثى و همجنين محرك ادبال غمَين در برابر محركهاى

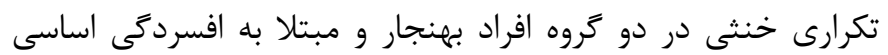
معنادار است (ه • • P<). با توجه به نتايج جدول ل، افراد مبتلا به اختلال افسردگى اساسى در اين تكليف دجار كمتر سنجى مىشوند؛ و زمان

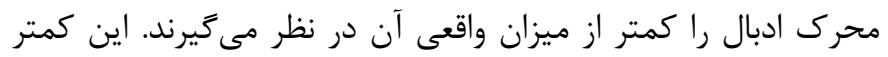

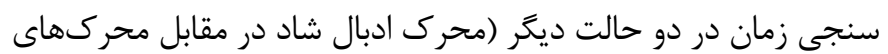

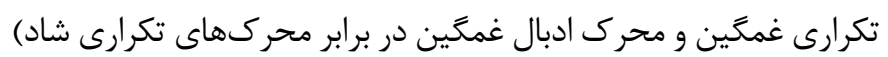
نيز وجود داشت ولى نه به ميزانى كه اين اختلاف معنادار باشد.
نتايج يافتهاى توصيفى مربوط به ادراك زمان حالات هيجانى مختلف به تفكيك گروهها نشان داد كه در حالت قرار گرفتن محرك ادبال شاد در برابر محركهاى تكرارى خننى، ميانكَين و انحراف معيار كره

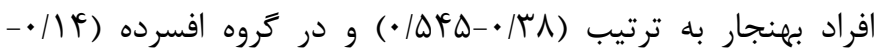

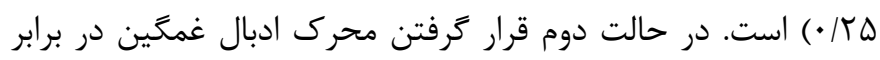

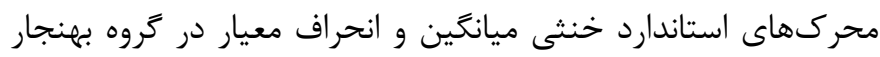

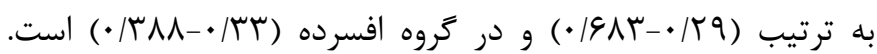
در حالت سوم قرار كرفتن محرى ادبال غمخين در برابر محركهاى دراي استاندارد شاد ميانگين و انحراف معيار در گروه نرمال به ترتيب (هَr/• •

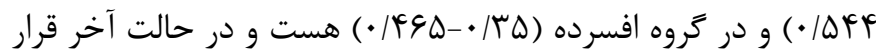
كرفتن محرك ادبال شاد در مقابل محرك هاى تكرارى غمَّين ميانكَين

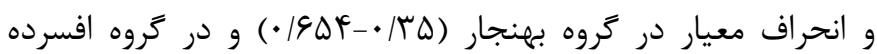

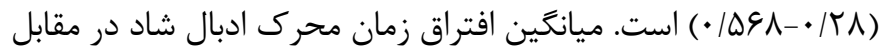
محرك هاى خنثى همان كونه كه مشاهده مىشود در هر جهار محرك

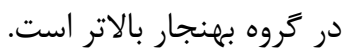
بر اساس يافتههاى به دست آمده در جدول ل، بين ميانگين نمرات ادراك

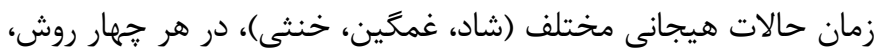


جدول ا. نتايج تحليل واريانس خند متغيره، متغيرهاى ادراى زمان حالات هيجانى مختلف در دو كروه

\begin{tabular}{|c|c|c|c|c|c|c|c|c|}
\hline توان آمارى & اندازه اثر & $\mathbf{P}$ & آزادى خرجها & فرآزادى & $\mathbf{F}$ & ضريب & اثرات در گروه & \\
\hline$\cdot / V Y V$ & $\cdot / r \Delta V$ & . & r & f & $r / 199$ & $\cdot / r \Delta V$ & اثر پِيلايى & \multirow{4}{*}{ حالتهانى } \\
\hline - IVTV & $\cdot / r \Delta V$ & It/. & זr & f & $4 / 199$ & . lext & لامبداى ويلكز & \\
\hline$\cdot / V H V$ & $\cdot / r \Delta V$ & I. & r & r & $r / 199$ & $\cdot \mid \Delta \Delta \varphi$ & اثر هتلينَ & \\
\hline$\cdot / V H V$ & $\cdot / r \Delta V$ & (1. & זr & f & $4 / 199$ & $\cdot \mid \Delta \Delta \Phi$ & بزرگترين ريشه روى & \\
\hline
\end{tabular}

جدول ז. نتايج حالتهاى مختلف هيجانى مختلف قرار كرفتن محرك ادبال در برابر محركهاى تكرارى در دو كروه

متغير

\begin{tabular}{|c|c|c|c|c|c|c|c|}
\hline - /VSV & וTI/. & $.1 \cdot 1$ & V/V৭৭ & $\cdot 19 \cdot 1$ & 1 & $\cdot 19 \cdot 1$ & محرك محهاى ادبال شكاد در مقابل \\
\hline $.199 \mathrm{~V}$ & .1194 & $.1 \cdot r$ & s/lve & $\cdot|9|$ & 1 & $\cdot|9|$ & محرك ادبال غمگين در مقابل \\
\hline$\cdot 1 \cdot 19$ & $.1 \cdot 1 \mathrm{~F}$ & $\cdot \mid \Delta \Delta \varphi$ & $\cdot / r \Delta V$ & . & 1 & r & محرك ادبال غمگين در مقابل \\
\hline$\cdot 11 \cdot 1$ & $.1 \cdot r$ & $\cdot / 4 \Delta V$ & . IDTG & $\cdot|\cdot \Delta|$ & 1 & $\cdot \mid \cdot \Delta 1$ & محرى محى ادبال شاد در مقابل \\
\hline
\end{tabular}

مىدهد كه يديده سركوب تكرار مىتواند بر ادراك مدت زمان افراد نرمال اثر بحذارد و ارائه محرك هاى هيجانى اثر جندانى بر اين قضيه در افراد عادى نداشته است. طبق نظر Eagleman داراى بار عاطفى بودن محرك نمىتواند اثرى بر روى قضيه سركوب تكرار داشته باشد و در هر صورت محرك جديد وقتى در كنار محركهاى تكرارى قرار مى گيرد طولانىتر به نظر مىرسد (هَ). از طرفى در گروه افسرده نتايج متفاوت بود و افراد گرايش به كمتر تخمين زدن زمان محرك ادبال داشتند. در هر جهار حالت گرايش به كمتر سنجى زمان محرك ادبال وجود داشت ولى در دو حالت اول قرار گرفتن محرك ادبال شاد و غمخين در مقابل محركهاى تكرارى خنثى اين اختلاف نمرات باعث ايجاد تفاوت معنادار بين دو گروه شد. اين نتايج نشان مىدهد محرك مهاى هيجانى احتى
نتايج مطالعه حاضر نشان داد افراد مبتلا به اختلال افسردگى اساسى الكوى متفاوتى از افتراق زمان را نسبت به افراد بهنجار داشتند. در گروه بهنجار افراد تمايل به بيش تخمينى محرك ادبال در هر جهار حالت داشتند. اين يافته مطابق با يديدهى سركوب تكرار بود كه در آن ارائهى تكرارى محركها باعث كاهش ڤֶاسخ عصبى به محرك مىشود در نتيجه منجر به مدت زمان درك شدهى كوتاهتر مى جديد در بين محركهاى تكرارى باعث افزايش فعاليت مناطق مختلف مغز مى گردد و فرد تخمين بيشترى از مدت زمان ارائهى محرك ادبال

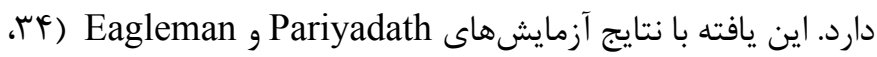
ها") بر روى محركهاى ديدارى و همجنين نتايج مطالعات نظرى و جلال كمالى (T) بر روى محرك مهاى شنيدارى همسو است و نشان 
كوتاهتر به نظر مىرسد (9). سؤالى كه يرسيده مىشود اين است كه 尹را در افراد افسرده، ساعت درونى كندتر حركت مى كند؟ بر اساس

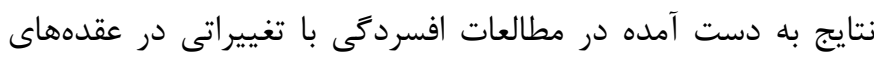

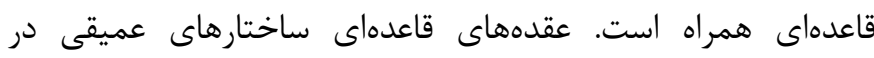
مغز هستند كه مسئول كنترل حركت، ياسخ به ياداش و و همجنين

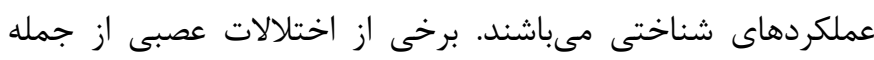

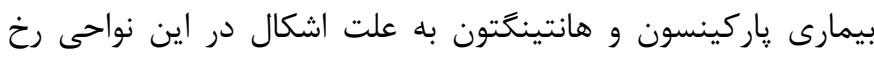

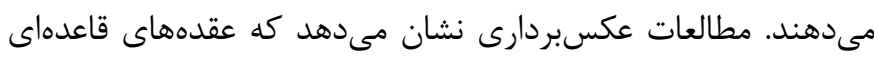
علاوه بر اينكه در عملكرد حركتى دخالت دارند نقش اوليه را در ادراك زمان بازى مى كنند (أl). به علاوه بيماران پاركينسونى و افراد افسرده،

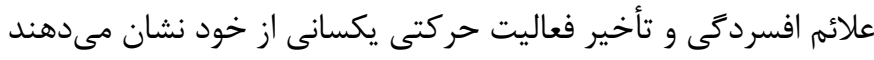
و مشكلاتى در زمينه ادراك زمان دارند (TF)؛ بنابراين كمتر سنجى

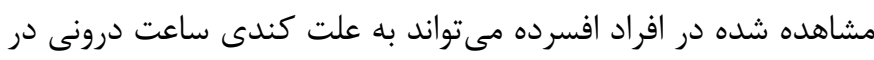

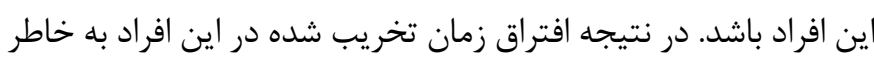

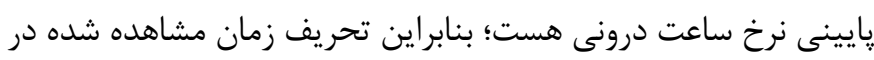

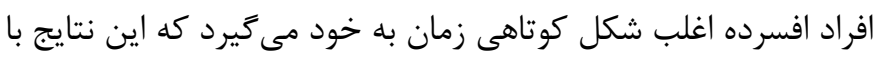

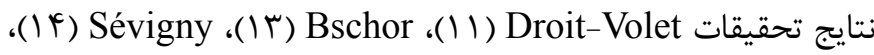

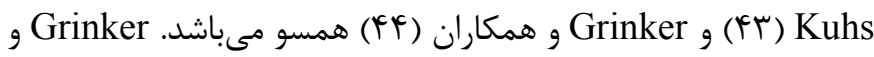
همكاران در مطالعهاى نشان دادند افراد افسرده زمان را كمتر تخمين

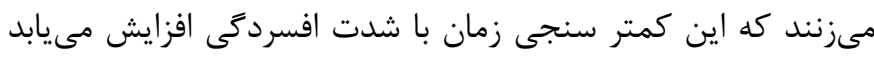

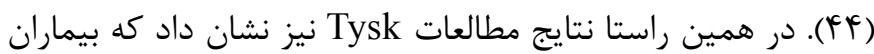

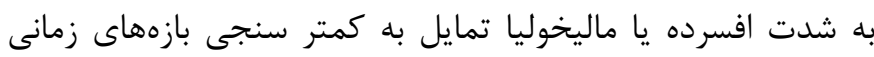

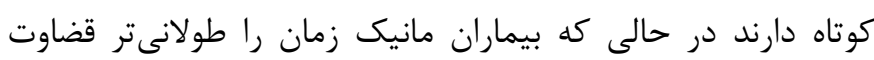

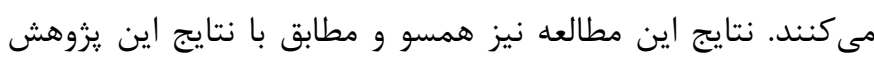

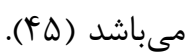

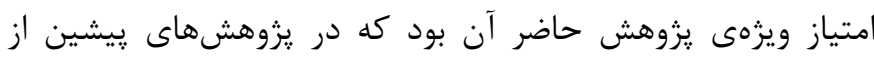

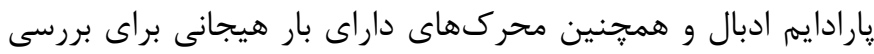

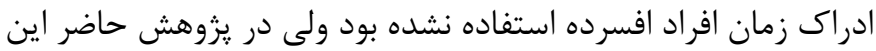

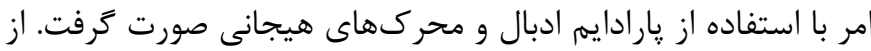
محدوديتهاى يزوهش حاضر مىتوان به عدم ارزيابى توجه، حافظه

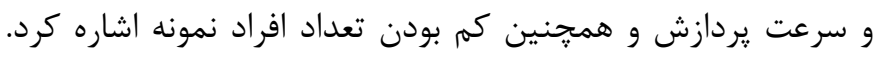

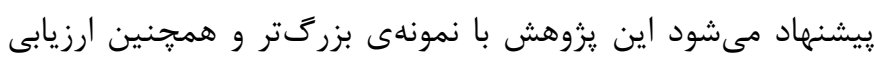
عملكردهاى اجرايى افراد، تكرار شود.

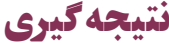
خلق غم در افراد افسرده با كندى سرعت ساعت درونى در ارتباط است كه كندى سرعت ساعت باعث كمتر تخمينى زمان مىشود. همجنين اختلال
مىتوانند اثر بيشترى بر روى افراد افسرده نسبت به افراد عادى داشته

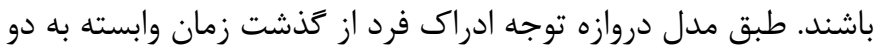
عامل ميزان توليد پالس توسط ضربانساز و ميزان توجه فرد به كَذر زمان است. هر جه قدر קالس بيشترى توليد شود و هر جقدر توجه فرد

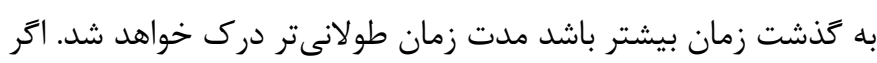

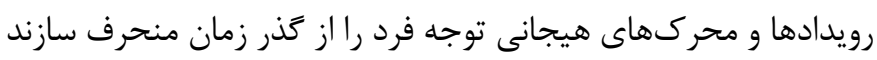

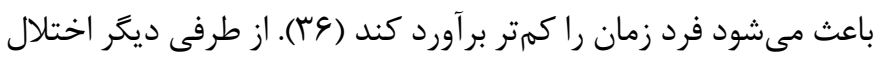
در توجه پايدار، انتخابى و كنترل شده در بيماران افسرده اثبات شده است. مطالعات تصويربردارى نابهنجارىهايى در شبكه ييش پيشاني ماند كرتكس ييش يیشانى يشتى جانبى Dorsolateral Prefrontal)

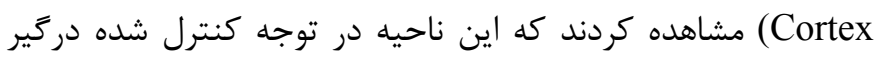

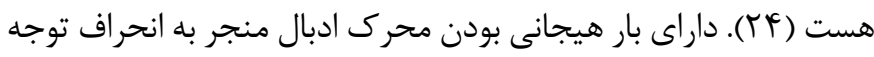

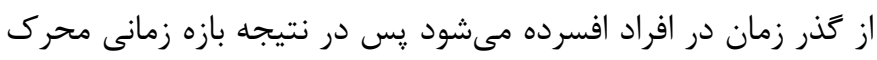

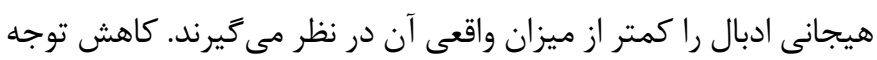
كنترل شده عامل خطرى براى نفوذ افكار منفى در حافظه أنس كارى افر افراد

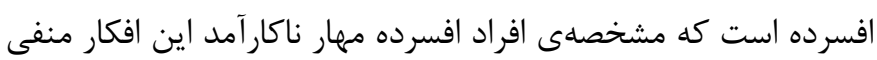

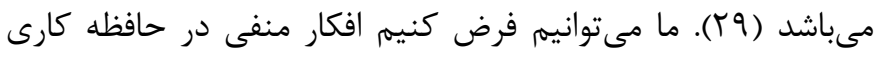

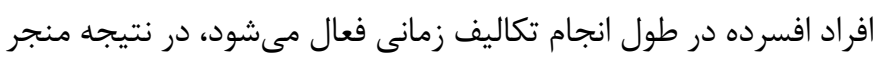
به تحريف در زردازش زمان در اين افراد مى كردد. همجنين مشكل

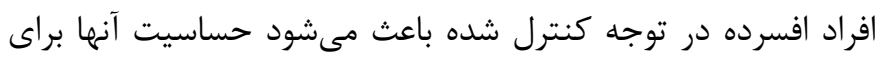
زمانهاى طولانى كاهش يابد (^ץ).

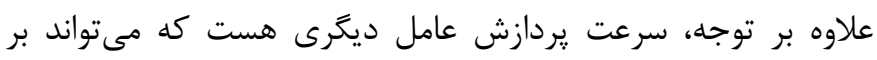

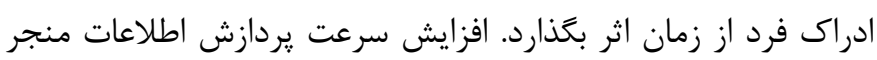

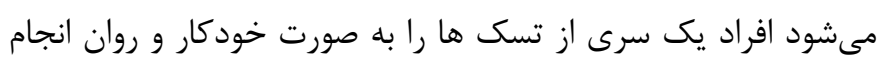

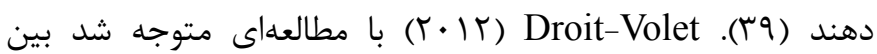
حساسيت به زمان و سرعت يردازش اطلاعات همبستخى معنادارى وجود دارد. سرعت يردازش سريعتر منجر به حساسيت بيشتر فرد به

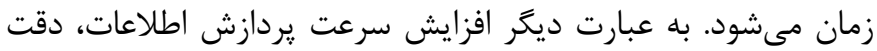

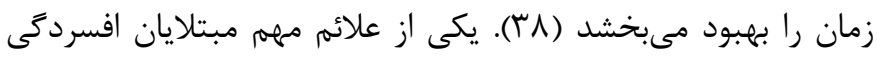

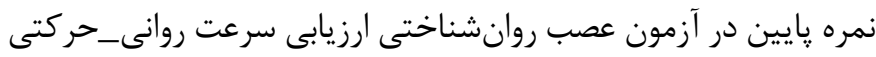

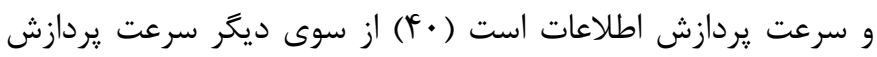

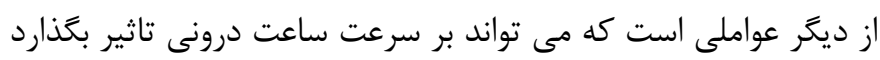

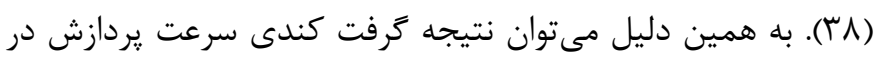
افراد افسرده با كندى ساعت درونى در ارتباط است. بيشتر محققان بر اين باورند كه تفاوتهاى مرتبط با افسردىى در ادراك زمان، به خاطر سرعت ساعت درونى مىباشد كه در افراد آهستهتر حركت مى كند در نتيجه يالس كمترى توليد مىشود و بازه زمانى 


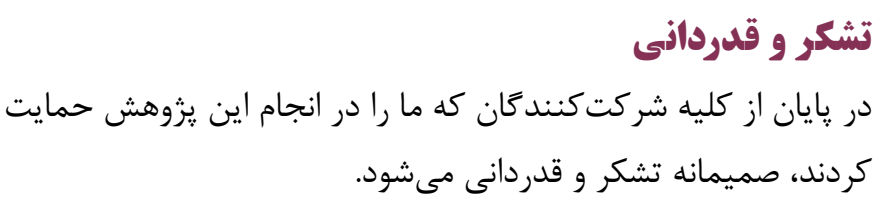

كردند، صميمانه تشكر و قدردانى مىشود.

\section{References}

1. Toplak ME, Rucklidge JJ, Hetherington R, John SC, Tannock

R. Time perception deficits in attention-deficit/hyperactivity disorder and comorbid reading difficulties in child and adolescent samples. Journal of Child Psychology and Psychiatry. 2003;44(6):888-903.

2. Allman MJ, Meck WH. Pathophysiological distortions in time perception and timed performance. Brain. 2011;135(3):656677.

3. Vicario CM. Cognitively controlled timing and executive functions develop in parallel? A glimpse on childhood research. Frontiers in Behavioral Neuroscience. 2013;7:146.

4. Brown R. Hyperactivity: Assessment and evaluation of rating instruments. Journal of Psychiatric Treatment and Evaluation. 1982;4:359-369.

5. Smith A, Taylor E, Warner Rogers J, Newman S, Rubia K. Evidence for a pure time perception deficit in children with ADHD. Journal of Child Psychology and Psychiatry. 2002;43(4):529-542.

6. Yang B, Chan RC, Zou X, Jing J, Mai J, Li J. Time perception deficit in children with ADHD. Brain Research. 2007;1170:90-96.

7. Barkley RA. Attention deficit/hyperactivity disorder: A handbook for diagnosis and treatment. 3rd Ed. New York:Gilford Press;2007.

8. Egeland J, Rund BR, Sundet K, Landrø NI, Asbjørnsen A, Lund A, et al. Attention profile in schizophrenia compared with depression: differential effects of processing speed, selective attention and vigilance. Acta Psychiatrica Scandinavica. 2003;108(4):276-484.

9. Ratcliffe M. Varieties of temporal experience in depression.

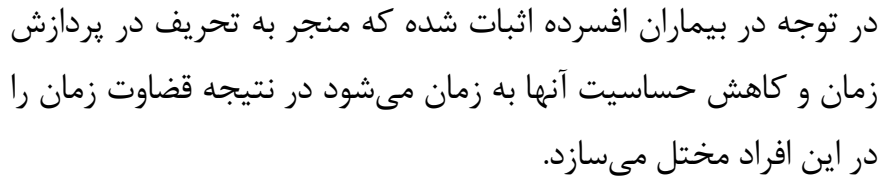

Journal of Medicine and Philosophy. 2012;37(2):114-138.

10. Gallagher S. Time, emotion, and depression. Emotion Review. 2012;4(2):127-132.

11. Gil S, Droit-Volet S. Time perception, depression and sadness. Behavioural Processes. 2009;80(2):169-176.

12. Oberfeld D, Thönes S, Palayoor BJ, Hecht H. Depression does not affect time perception and time-to-contact estimation. Frontiers in Psychology. 2014;5:810.

13. Bschor T, Ising M, Bauer M, Lewitzka U, Skerstupeit M, Müller-Oerlinghausen B, Baethge C. Time experience and time judgment in major depression, mania and healthy subjects. A controlled study of 93 subjects. Acta Psychiatrica Scandinavica. 2004;109(3):222-229.

14. Sévigny MC, Everett J, Grondin S. Depression, attention, and time estimation. Brain and Cognition. 2003;53(2):351-353. 15. Thönes S, Oberfeld D. Time perception in depression: A meta-analysis. Journal of Affective Disorders. 2015; 175:359-372.

16. Lemke MR, Koethe N, Schleidt M. Segmentation of behavior and time structure of movements in depressed patients. Psychopathology. 2000;33(3):131-136.

17. Treisman M. Temporal discrimination and the indifference interval: Implications for a model of the" internal clock”. Psychological Monographs: General and Applied. 1963;77(13):1-31.

18. Ivry RB, Schlerf JE. Dedicated and intrinsic models of time perception. Trends in Cognitive Sciences. 2008;12(7):273-280. 19. Meck WH, Benson AM. Dissecting the brain's internal clock: how frontal-striatal circuitry keeps time and shifts attention. Brain and Cognition. 2002;48(1):195-211. 
20. Eagleman DM, Pariyadath V. Is subjective duration a signature of coding efficiency?. Philosophical Transactions of the Royal Society B: Biological Sciences. 2009;364(1525):1841-1851.

21. Marchetti G. Studies on time: A proposal on how to get out of circularity. Cognitive Processing. 2009;10(1):7-40.

22. Eagleman DM. Human time perception and its illusions. Current Opinion in Neurobiology. 2008;18(2):131-136.

23. Nazari MA, Jalalkamali H. The effect of repetition suppression phenomenon and frequency of the auditory stimulus on perceived duration. Applied Psychological Research Quarterly 2015;6(1):49-60. (Persian)

24. Grondin S. Timing and time perception: a review of recent behavioral and neuroscience findings and theoretical directions. Attention, Perception, \& Psychophysics. 2010;72(3):561-582.

25. Nazari MA, Mirloo MM, Asadzadeh S. Time perception error in the processing of emotional persian words. Advances in Cognitive Science. 2012;13(4):37-48. (Persian)

26. Gilbert P. Evolution and depression: Issues and implications. Psychological Medicine. 2006;36(3):287-297.

27. Baert S, De Raedt R, Koster EH. Depression-related attentional bias: The influence of symptom severity and symptom specificity. Cognition and Emotion. 2010;24(6):1044-1052.

28. Judd LL, Kunovac JL. The prevalence and consequences of depressive disorders comorbid with general medical illnesses. In Mendlewicz, J, Brunello N, Judd LL, editors. New Therapeutic Indications of Antidepressants. Basel:Karger Publishers;1997. pp. 1-11.

29. Koster EH, Leyman L, De Raedt R, Crombez G. Cueing of visual attention by emotional facial expressions: The influence of individual differences in anxiety and depression. Personality and Individual Differences. 2006;41(2):329-339.

30. Nazari M, Mirloo MM, Soltanloo M, Rezaei M, Roshanei A, Asadzadeh S. Design and development of the time discrimination threshold computerized task. Advances in Cognitive Science.2013;15(1):1-10. (Persian).

31. Beck AT, Steer RA, Brown GK. Manual of the Beck inven-
tory-II. San Antonio TX:Psycho corporation;2000.

32. Dabson E, Mohammadhkani P. Psychometric characteristics of beck depression inventory-II in patients with major depressive disorder. Journal of Rehabilitation. 2007;29(8):82-88. (Persian)

33. Rajabi G, Atari Y, Haghighi J. Factor analysis of Beck depression inventory in boy students of Shahid Chamran University. Journal of Educational Psychology. 2001;8(3):4966. (Persian)

34. Pariyadath V, Eagleman D. The effect of predictability on subjective duration. PloS One. 2007;2(11):e1264.

35. Pariyadath V, Eagleman D M. Subjective duration distortions mirror neural repetition suppression. PloS One. 2012;7(12):e49362.

36. Gil S, Droit-Volet S. How do emotional facial expressions influence our perception of time? In Masmoudi S. Yan Dai D, Naceure A, editors. Attention, representation and human performance integration of emotion and motivation. London:Psychology Press, Taylor and Francis;2011.

37. Price JL, Drevets WC. Neurocircuitry of mood disorders. Neuropsychopharmacology. 2010;35(1):192-216.

38. Droit-Volet S. Time perception in children: A neurodevelopmental approach. Neuropsychologia. 2013;51(2):220-234.

39. Salthouse TA. The processing-speed theory of adult age differences in cognition. Psychological Review 1996;103(3):403-428.

40. Tsourtos G, Thompson JC, Stough C. Evidence of an early information processing speed deficit in unipolar major depression. Psychological Medicine. 2002;32(2):259-265.

41. Matell MS, Meck WH. Cortico-striatal circuits and interval timing: coincidence detection of oscillatory processes. Cognitive Brain Research. 2004;21(2):139-170.

42. Harrington DL, Haaland KY, Knight RT. Cortical networks underlying mechanisms of time perception. Journal of Neuroscience. 1998;18(3):1085-1095.

43. Kuhs H, Hermann W, Kammer K, Tölle R. Time estimation and the experience of time in endogenous depression (Mel- 
ancholia): an experimental investigation. Psychopathology. 1991;24(1):7-11.

44. Grinker J, Glucksman ML, Hirsch J, Viseltear G. Time perception as a function of weight reduction: a differentiation based on age at onset of obesity. Psychosomatic Medicine. 1973;35(2):104-111.

45. Tysk L. Time perception and affective disorders. Perceptual and Motor Skills. 1984;58(2):455-464. 